

SOCIAL SCIENCES

\title{
Conceptual model about the entrepreneurial university: design and validation with the PLS methodology
}

\author{
DANIEL HERNÁN VALERA-LOZA, JULIO GARCÍA DEL JUNCO \& BEATRIZ PALACIOS- \\ FLORENCIO
}

\begin{abstract}
The entrepreneurial university is a growing trend in higher education. Almost three decades of research with studies centred on successful cases from Anglo-Saxon countries serve as a reference for high-income countries. However, these cases cannot be applied to the Latin American reality, as it has distinct circumstances: high rates of informality, of business mortality, low education and scant research. This study analyses, via the technique of structural equation models, the relations between the cultural aspects of the entrepreneurial university, the carrying out of applied research and the creation of firms by university centres. With a sample of students of the University of San Martín de Porres (Peru), the existence of positive relations between the distinct variables which make up the idea of the entrepreneurial university is noted (entrepreneurial leadership, entrepreneurial curriculum, entrepreneurial culture, applied research, and firm creation and technology transfer). Also, in the area of nonAnglo-Saxon universities a positive effect of the impulse of entrepreneurial behaviours and activities on the starting up of new business initiatives by university graduates is observed.
\end{abstract}

Key words: Entrepreneurial university, OTIs, spin-offs, innovation, Peru, PLS.

\section{INTRODUCTION}

The relation of the university with the development of culture via professional training, research and university impact forms part of its raison d'être. The socio-economic trends of the last three decades demand from the university new challenges and functions (Foss \& Gibson 2015). The concept of "the Entrepreneurial University" has arisen as a response. This is understood as an institution which capitalises or commercialises knowledge with the intention of the business sector and society using it (Etzkowitz 2013, Humberto et al. 2019).

The research on university entrepreneurship highlights that universities of countries with high incomes have a strong commitment with the development of entrepreneurial capacities among their students and graduates (Braidot 2001). In the case of Latin American universities, according to Valera-Loza (2006) and Pineda (2015), the actions proposed are simply descriptive and appear isolated and disjointed.

The empirical analysis of universities and their entrepreneurial activity is in its early stages. The majority of the international literature is centred on case studies, focused on the results or products (number of spin-offs, royalty incomes, etc.), or on successful cases (Allen \& O'Shea 2014). The indicators obtained in these studies have not been tested quantitatively. 
The use of qualitative studies is useful to identify relevant aspects of the entrepreneurial university, although it is not suitable to establish the reliability and validity of a multidimensional conceptual model. This is why in this research the following objectives are sought. Firstly, to present a conceptual model which enables identifying, defining and describing the Peruvian entrepreneurial university. Secondly, to establish the reliability and validity of the proposed conceptual model via the use of a quantitative method. Lastly, to develop and validate the instruments necessary to measure the variables included in the proposed model.

To accomplish these aims this work is structured in the following manner. First the state of the art of the entrepreneurial university is analysed, both at the conceptual and at the strategic level: the origin, the delimitation of the term, the conceptual model proposed and the research hypotheses. In the methodological section information is offered about the design used, the participants selected, the indicators and dimensions which make up the measurement instrument and the analysis technique selected: Variance-Based Structural Equation Modelling, under Partial Least Squares (PLS). Next, the research results are presented, taking the University of San Martín de Porres as the case analysis: the entrepreneurial profile of the university, and the reliability and validity of the conceptual model. Finally, the findings are discussed, the conclusions are presented, and new research lines are proposed.

\section{REVIEW OF THE LITERATURE}

The research line called "the entrepreneurial university" integrates the general theory of entrepreneurship and the theory of higher education, and its importance has been underscored in both the academic area and the political area. Various studies (Audretsch et al. 2006, Hidalgo \& Molero 2008, Hahn et al. 2019) have demonstrated the essential character of innovative entrepreneurship as a seed for economic growth (Munger 2015); and the role of universities stands out in that work, university research in particular (Audretsch 2014).

The study of the entrepreneurial university has been done from a double perspective: the internal, following Burton Clark (1998), and the external, in the steps of Henry Etzkowitz (2013, 2004). Within the framework of the internal perspective, the entrepreneurial university is an institution which has adapted to social and economic needs and that, consequently, has successfully faced the processes of adaptation to a new environment via adopting changes which enable it to raise its capacities of response and adaptation (Brunner 2006). For the external perspective, in the words of Etzkowitz (2002), the entrepreneurial university is a new academic model where teaching and research are combined in the capitalisation of knowledge. Key in this definition of the entrepreneurial university is the close relation between the society and the university (Mautner 2005), which is materialised in the famous "triple helix" of Etzkowitz \& Leydesdorff (1996) about the relation between the university, the government and the firm, and that offers new opportunities and greater resources for economic development.

Assuming an integrated perspective of both approaches, it should be pointed out that the entrepreneurial university internally sees its students and civil servants as potential entrepreneurs. It centres itself on achieving that its research results can improve the social conditions of its environment. Thus, the entrepreneurial university takes advantage of technological transfer to foster high aggregated value firm creation and promotes the 
development of entrepreneurs (Paunovic 2007, Rodeiro et al. 2008).

Academic entrepreneurship refers to the process of creating firms within the academic context, specifically firms with a technological base or based on research results(Shane2004). On the contrary, the concept of the entrepreneurial university defines the characteristics and goals of a higher teaching institution which fosters academic entrepreneurship.

The entrepreneurial university is a university with a more "business" view, flexible, and having a capacity of adaptation and creativity to satisfy the current needs of society and to foresee the future, offering new study lines, new research areas and a deeper collaboration with the social and economic environment (Clark 1998, Etzkowitz 2004).

\section{Proposal of a conceptual model of the entrepreneurial university}

The academic literature presents a series of definitions for the entrepreneurial university, with various indictors, which does not permit a universal consensus concerning the elements which compose it (Meyers \& Pruthi 2011, Salamzadeh et al. 2011). Many of the variables nowadays typified as characteristic of an entrepreneurial university have been investigated before the birth of the concept.

In this research we propose using a processes-based management model to define the Entrepreneurial University. This model organises the relation of nine dimensions of the concept, which have been born from the diverse international proposals (Morales-Gualdrón 2008, Sharma \& Chrisman 1999).

These dimensions are: entrepreneurial leadership, entrepreneurial culture, an entrepreneurial curriculum, entrepreneurial support, diversified financing sources, applied research, interaction networks, university-firm intermediation offices, firm creation and technology transfer (see Figure 1).

From the model it is to be highlighted that entrepreneurial leadership (decentralised and flexible) is a dimension of the transversal Entrep reneurial University in all the process, from the input to the output. A flexible leadership, centred on results and which decentralises power towards the mid-level controllers is essential to dynamise all the entrepreneurial university system.

The cultural dimensions of entrepreneurial management correspond to the promotion of entrepreneurial culture and an entrepreneurship-oriented curriculum. Both facilitate entrepreneurial orientation and attitudes favourable to the businesses of the internal stakeholders (teachers and students); but it is the structural dimension which will make it a reality. Indeed, the internal business support of the initiatives (e.g., incubators) and university-firm intermediation furthers the development of strong external sources, laying the groundwork for entrepreneurial initiatives (science and technology firms, spin-offs) and generating diversified incomes which provide feedback to all the system. Furthermore, research is enriched by the access to primary sources and entrepreneurial culture as well as having successful cases and teachers directly involved in these projects.

On the basis of the 9 dimensions proposed in the conceptual model shown in Figure 1 and the prior studies on entrepreneurial universities a model is presented of the relations between the variables and the hypotheses which we aim to validate in our empirical research are specified. The model of relations is shown in Figure 2. Nonetheless, in this work only a part of this model is going to be validated, that related with cultural aspects. 


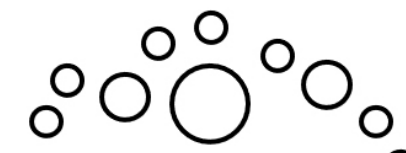

Act as entrepreneurial $\mathrm{O}$

$\mathrm{O}$ organisation

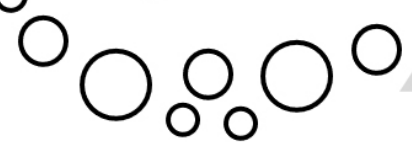

Entrepreneurial leadership
Promote entrepreneurship among its internal stakeholders

- Entrepreneurial culture

- Entrepreneurial curriculum

- Entrepreneurial support

- Financing sources

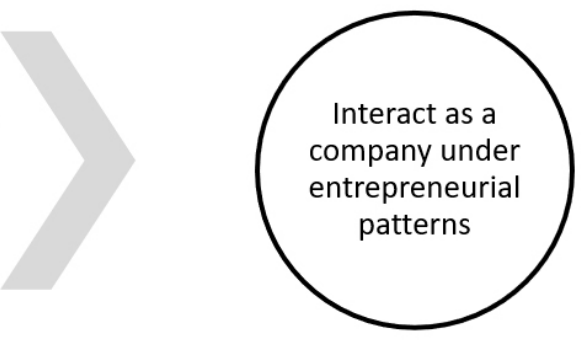

Applied research Interaction networks

University-firm intermediation

Firm creation and technology transfer

Figure 1. Operational definition of the Entrepreneurial University: Goals-Means.

Source: Own elaboration based on Röpke (1998).

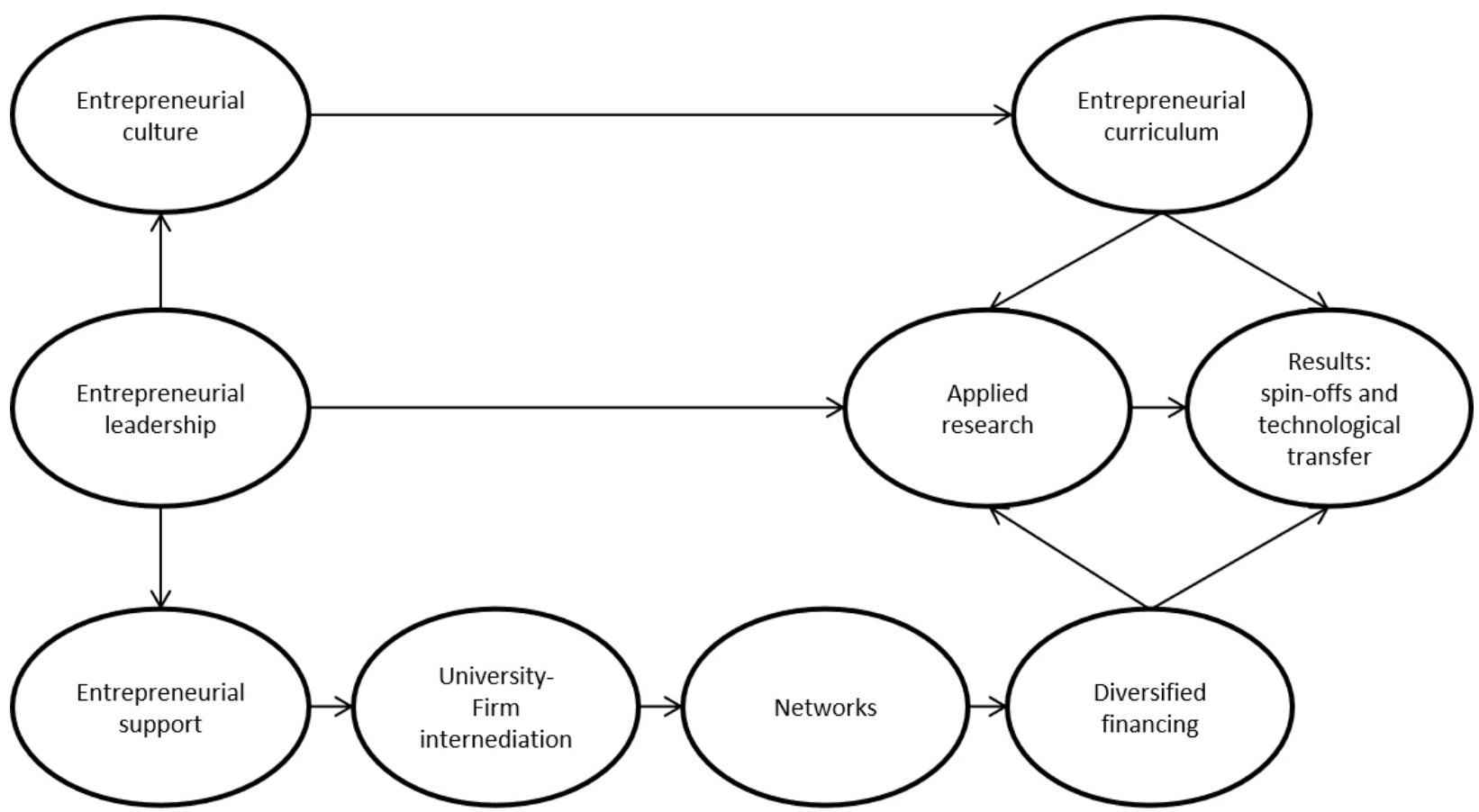

Figure 2. Conceptual model of relations between the dimensions of the Entrepreneurial University. Source: Own elaboration.

\section{Entrepreneurial leadership}

Farnham (1999) distinguishes between four university management models, on the basis of the interaction between the professional autonomy of the scholars and their participation in the government of the university. The collegiate model is characterised by high professional autonomy and high participation. In the management model (dominant in private universities) both participation in the management and academic autonomy are less. 
The bureaucratic model allows a certain degree of academic autonomy along with a high regulation of the participation in the management. The entrepreneurial model is targeted more at effectiveness and efficiency than at centralised authority, so the academic autonomy is limited to fulfilling the entrepreneurial goals and the scholars participate in the management of the diverse activities oriented towards the production of results and the obtaining of incomes.

In the entrepreneurial university, the top management fosters the entrepreneurial attitudes of all the workers, generating an appropriate work environment for the identification of new opportunities, motivating entrepreneurial behaviours, not punishing entrepreneurial failure and promoting the creation of formal and informal networks which facilitate achieving resources to take advantage of opportunities (Morales-Gualdrón 2008). To achieve these aims, the university management creates an organisational context which stimulates seeking entrepreneurial opportunities, making this socially desirable, and fostering the development of individual and group capacities to exploit new opportunities. To sum up, it creates the conditions which support entrepreneurship and stimulates an entrepreneurship-oriented culture (Harrison et al. 2018).

All this leads us to make the following proposals. Firstly, the adopting of an entrepreneurial leadership approach, characteristic of the entrepreneurial university, involves the development of a strong entrepreneurial culture. Secondly, a strong boosting of the entrepreneurial leadership of a university is manifested in a high growth of the support centres towards entrepreneurship. Thirdly, high levels of entrepreneurial leadership lead to the carrying out of more applied research.

\section{Applied research}

Research in entrepreneurial universities is linked to the management of the knowledge itself, via instruments proactive for transfer (interdisciplinarity; organisation for collaborative $\mathrm{R}+\mathrm{D}$; protection and licence management; capacities in management of spin-offs). Moreover, it generates new infrastructures and spaces for transfer (Mixed institutes, Technological platforms, shared laboratories, Centres of reference, Science parks, etc.) which optimise the generation of useful knowledge and technology transfer (Brunner 2006).

Derived from all the aforementioned, we indicate the following proposal of our conceptual model: the applied research of entrepreneurial universities has a favourable effect on the academic results in terms of firm creation, specifically of academic spin-offs.

\section{Cultural management of entrepreneurship}

Entrepreneurial universities not only make structural changes in their organisation, they also foster a favourable environment for firm creation, particularly among university students and researchers. They promote the entrepreneurs' ideas via competitions, fairs or contests; they organise meetings of consolidated entrepreneurs with entrepreneurs, and diffuse new values and practices. In brief, they generate, foster and consolidate an institutional culture of entrepreneurship (Khan \& Ahmed 2019).

Entrepreneurial universities usually develop an entrepreneurship-oriented curriculum, with subjects related to firm creation, with academic support for new ideas. By this it is meant to endow students with the tools and competences necessary to create and maintain firms. The absence of excellent managerial competences among the founders of academic spin-offs drives entrepreneurial universities to facilitate training courses, direct support in incubators 
and Offices of Technology Transfer (OTIs); in sum, to offer academic entrepreneurship-oriented curriculums.

Three proposals stem from these comments. First, that the presence of a strong entrepreneurial culture in the university involves the creation of academic curriculums centred on entrepreneurship. Second, the development of an entrepreneurial academic curriculum fosters the existence of an applied research approach. Lastly, the existence of an entrepreneurshiporiented university curriculum is directly and positively related with the creation of new firms and the founding of university spin-offs.

\section{Structural management of entrepreneurship}

The area of the structural management of entrepreneurship by entrepreneurial universities includes four dimensions of the proposed model: centres of entrepreneurial support, structures which favour university-firm intermediation, the existence of strong networks of inter-relation and collaboration and, finally, the offer of diversified financing sources.

The entrepreneurial leadership spirit of entrepreneurial universities leads them to create offices and spaces of support and consultancy for the creation of firms. These are useful spaces to give support to the birth and initial growth of firms with a university base, as they collaborate with infrastructures, consultancies, technical support, and follow-up, among others (Valls et al. 2008). These activities tend to be called "incubators" and are usually very effective, having a success rate of between 80 and 93\% (Pérez \& Márquez 2006). For Etzkowitz (2013) the university is a natural incubator, as it has flexible resources, staff and human resources which are not expensive; also, it has students that it can organise to assume new projects.

In addition to incubators, entrepreneurial universities tend to deploy institutional structures geared to enabling intermediation between the university and firms. These units transfer knowledge from the university towards firms (Valls \& Condom 2003). There exist four forms of university-firm interaction: a) research contracts, b) consultancies, c) technological licences, and d) technological development and commercialisation (Cargill 2007). The units of intermediation can take on the following forms: Offices of Technology Transfer (OTIs); Innovation centres; Technological Centres; Science Technological Parks; Laboratories of Trial and Homologation; Services of support to research and innovation; Technological platforms; Patent centres; Incubators of innovative firms.

The entrepreneurial university is an institution capacitated to work in a network, thus guaranteeing the articulation with firms, governments and $\mathrm{R}+\mathrm{D}$ centres foreign to it. Indeed, entrepreneurial universities tend to work with other social actors, dynamising complex projects and networks of innovation and entrepreneurship. A university is not really an entrepreneurial university if it does not attain financial awareness; that is to say, the capacity to commercialise its products and generate a surplus which enables it to finance a deficit in other areas or cuts in public financing.

Due to all this, the following proposals are offered in the model. First, the presence of solid centres of entrepreneurial support contributes to a greater performance of the mechanisms of university-firm intermediation. Secondly, the existence of university-firm intermediation units improves the contact networks of the entrepreneurial university. Third, strong networks of contacts of the university make the setting up of diversified sources of financing easier. Fourth, there being multiple financing sources of the university favourably conditions the generation of applied research. Lastly, the possibility of accessing different financial means offered by 
the university is a determinant element of the number of firms created by the members of the university.

\section{Management of results}

The creation of university firms, known as academic spin-offs, has become a priority within international policies. The contribution of innovator firms to the generation of highly qualified and stable employment, and to the economic development of the regions, has grown significantly, boosting the interest in them (Breztnitz \& Etzkowitz 2015, Shane 2004).

For Shane (2004) university spin-offs are new firms created to exploit a part of the intellectual property of an academic institution. They are established by current members of a university (students, teachers, employees) who commercialise intellectual property developed at the heart of the university.

\section{Practical application of the conceptual model of the entrepreneurial university}

The practical application proposed in this article is exclusively centred on the analysis of the relations of the variable entrepreneurial leadership and the cultural constructs (entrepreneurial culture and entrepreneurial curriculum) with the variables applied research and results (science and technology firms) as is shown in Figure 3. To do so we must indicate the characteristics of this context. Firstly, the leadership is not yet entrepreneurial, but hierarchical and collegiate. Secondly, the cultural dimension of entrepreneurship has been developed at the curricular level, but an entrepreneurial institutional culture has not yet been fostered. Thirdly, the scientific production is very low and is not oriented towards applied research.

Indeed, according to the data of the last Peruvian University Census (2010), only 4 of the 65 Peruvian private universities - the Universidad Católica del Perú, the Universidad de San Martín de Porres, the Universidad de Piura and the Universidad San Ignacio de Loyola - have firm incubators with diverse services which have been functioning for more than 5 years, and with firms incubated from its programmes. Others (13) have incubators in an initial phase

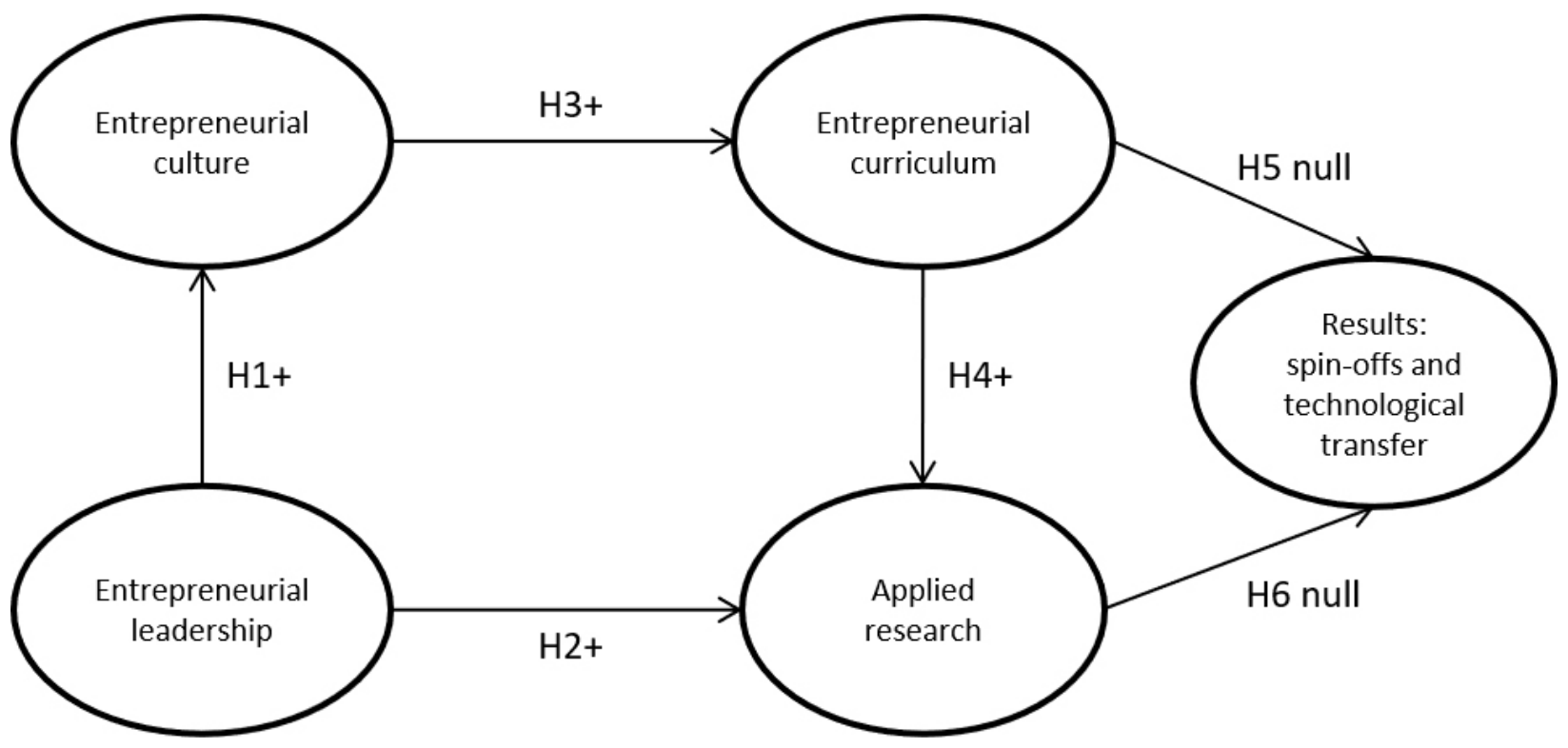

Figure 3. Research hypothesis. 
with services of training or in a pre-incubation phase. The rest of the universities $(n=48)$ do not have institutionalised firm incubators.

As to the entrepreneurial curriculum, $48.68 \%$ of undergraduate students state that in their universities they have entrepreneurship courses. In the same vein, $61.4 \%$ believe that their university contributes to the local development.

Regarding $R+D$, only $36.7 \%$ of the undergraduate students take part in research groups or research experiences in the university. On the other hand, only $47.88 \%$ of postgraduates have begun their Master thesis or doctorate research.

The scientific training of university teachers is worrying. Between 1996 and 2010 there has been a significant decrease of private university teachers who participate in scientific and/or cultural institutions (from $46.6 \%$ to $15.3 \%$ ), a value which represents half of the percentage in public universities. Also, only $31.6 \%$ of teachers state that they are subscribed to specialised publications. This would explain why only 31.5\% declare having done at least one research work in the previous two years.

This situation of the context of Peruvian private universities leads us to propose the following hypotheses in our model, shown in Figure 3. And the following six hypotheses:

Hypothesis 1 ( $\mathrm{H}_{1}$ ): The degree of entrepreneurial leadership of the University of San Martin de Porres has a positive effect on its entrepreneurial culture.

Hypothesis $2(\mathrm{H} 2)$ : The greater the applied research of a University, the greater its entrepreneurial leadership.

Hypothesis 3 (H3): The greater the level of entrepreneurial culture of a University, the more likely is the creation of academic curricula centred on entrepreneurship.

Hypothesis $4(\mathrm{H} 4)$ : The more developed are the academic curricula centred on entrepreneurship, the greater the impact on the entrepreneurial results (spin-offs and technological transfer).

Hypothesis 5 ( $\mathrm{H} 5)$ : The universities create entrepreneurial courses and programmes for their students, but as they are theoretical and lack structural support, the impact on the entrepreneurial results (spin-offs and technological transfer) will be null.

Hypothesis 6 (H6): The universities manage research but not with an applied approach, therefore the impact of research on entrepreneurial results (spin-offs and technological transfer) will be null.

All this is graphically brought together in the causal model presented in Figure 3.

\section{METHODOLOGY}

Now we present the main characteristics of the empirical study, indicating the information collection methods, the design of the measurement instrument and the statistical techniques used in the analysis.

\section{Data collection and research instrument}

The research hypotheses have been verified from the information obtained through the use of a self-reported structured questionnaire designed for this purpose. The questionnaire has been centred on the measuring of the 9 dimensions included in the proposed global conceptual model, although the research presented in this article is going to focus on only the 5 dimensions of the proposed empirical model.

The Universidad de San Martín de Porres has been chosen as a specific case to carry out the research. It is a university which is defined as entrepreneurial in its culture and that has campuses in different districts of Lima. 
To obtain the data we have worked with a sample made up a representative group of students and for the calculation of the minimum size of the sample the following formula has been used:

Where, $\mathrm{N}=$ size of universe; $\mathrm{p}=$ probability; $\propto$ =level of confidence; $d=$ estimation error; $z=$ critical value.

For the calculation of the sample 18 professional schools have been included, the faculties of Sciences of communication and Law being excluded as they do not have permits for the application of the questionnaires (Table I).
Nevertheless, the data employed in this work correspond to the first wave of questionnaires obtained, a total of 567 valid interviews, and whose demographic characteristics are the following. The average age of the students is 21.63 years old (S.D.=3.26), there being $42.5 \%$ men and $57.5 \%$ women. $52.2 \%$ of the students work (42.5\% as an employee and $9.7 \%$ in their own business). $96.5 \%$ refer to having their own company as being within their future plans.

A Likert scale self-reported questionnaire has been used, designed to evaluate the actions of the entrepreneurial university. The questionnaire is made up of 58 items, presented

Table I. Sample of students enrolled USMP.

\begin{tabular}{|c|c|c|c|c|}
\hline \multirow[b]{2}{*}{ Faculty or School } & \multicolumn{4}{|c|}{ Students } \\
\hline & Population & Sample & $\begin{array}{l}\text { Percentage } \\
\text { selected }\end{array}$ & $\begin{array}{c}\text { Level of } \\
\text { confidence/ } \\
\text { Sample error }\end{array}$ \\
\hline School of Administration & \multirow{6}{*}{9,836} & \multirow{6}{*}{877} & \multirow{6}{*}{$8.9 \%$} & \multirow{6}{*}{$97 \% / 3.5 \%$} \\
\hline School of International Business & & & & \\
\hline School of Human Resources & & & & \\
\hline School of Marketing & & & & \\
\hline School of Accounting and Financial Sciences & & & & \\
\hline School of Economic Sciences & & & & \\
\hline School of Computation and Systems Eng. & \multirow{7}{*}{ 4,101 } & \multirow{7}{*}{502} & \multirow{7}{*}{$12.2 \%$} & \multirow{7}{*}{$95 \% / 4.1 \%$} \\
\hline School of Electronic Eng. & & & & \\
\hline School of Industrial Eng. & & & & \\
\hline School of Civil Eng. & & & & \\
\hline School of Architecture & & & & \\
\hline School of Food Industries & & & & \\
\hline School of Aeronautics & & & & \\
\hline Faculty of Medicine & \multirow{4}{*}{7,211} & \multirow{4}{*}{656} & \multirow{4}{*}{$9.1 \%$} & \multirow{4}{*}{$97 \% / 4.2 \%$} \\
\hline School of Obstetrics & & & & \\
\hline School of Nursing & & & & \\
\hline Dentistry & & & & \\
\hline TOTAL & 21,148 & 2,035 & $10 \%$ & $96 \% / 2.5 \%$ \\
\hline
\end{tabular}

Note: The schools of social sciences are not included: Communication, Tourism, Psychology and Law. 
as statements of what the university does regarding entrepreneurship. The respondents are asked about their level of exposure to such an activity via a Likert-type scale range of six options which are Never/Don't know, Almost never, Not often, Often, Almost always and Always. With this way of scoring, the aim is to determine the level of exposure; that is to say, the dailiness of the diverse actions of the Entrepreneurial University or which are very present in student life.

\section{Procedure and data analysis}

The data collection was carried out following a standardised protocol: an application for permits in each centre and the administering the surveys during class hours. A copy of the questionnaire was handed out with the respective instructions, emphasising its confidential character. The total time of carrying out the questionnaires was approximately twenty minutes.

The information was transferred to a database with the IBM SPSS (version 23) statistics packet, using a matrix model where each variable represents a column and each subject represents a row. A quality control of each questionnaire was done, verifying the coherence between the physical questionnaire and the data being put into the digital matrix. The statistical analysis was then done, using the statistic packets and modules inserted in the statistics programme IBM SPSS version 23 and the SmartPLS version 3.2 programme (Ringle et al. 2015).

\section{RESULTS}

Only 567 surveys were valid for statistics analyses. We eliminated some surveys due to being incomplete and/or presenting inconsistencies in the answers.

\section{Reliability and validity of the dimensions of the concept of the Entrepreneurial University}

Table II shows the results of the analysis of internal reliability of the 5 dimensions which characterise entrepreneurial universities in the proposed model. The average values of the correlations between items, the Cronbach Alpha value and the Composite Reliability value are offered. In all the cases it is observed that the correlations between items are, on average, over 0.5, and the Cronbach Alpha value ranges between Alpha $=.887$ and Alpha $=.954$, indicating high levels of reliability due to internal consistency. The values of composite reliability confirm the analyses obtained previously, all dimensions having internal consistency values over 0.9 .

Table II. Reliability by internal consistency of the dimensions of the Entrepreneurial University.

\begin{tabular}{|c|c|c|c|c|}
\hline Dimensions & $\begin{array}{c}\text { Number of } \\
\text { items }\end{array}$ & $\begin{array}{c}\text { Average of } \\
\text { correlations }\end{array}$ & $\begin{array}{c}\text { Cronbach } \\
\text { Alpha }\end{array}$ & $\begin{array}{c}\text { Composite } \\
\text { reliability }\end{array}$ \\
\hline Decentralised and flexible leadership (LD) & 5 & .655 & .905 \\
\hline Applied research (IN) & 8 & .572 & .914 & .987 \\
\hline Science and technology firms (ECT) & 4 & .651 & .892 & .922 \\
\hline Entrepreneurial curriculum (CU) & 6 & .662 & .954 \\
\hline Entrepreneurial culture (CT) & 8 & .723 & .917 \\
\hline
\end{tabular}

Source: 567 surveys of students. Own elaboration. 
Table III notes that the variance extracted in each dimension is over 0.5 in all the cases, the dimensions of Entrepreneurial leadership and Research being those which have the lowest AVE. This is due to the 3 items indicated in the case of the Exploratory Factor Analysis.

As to the discriminant validity of the dimensions, the Fornell-Larcker criterion is used, where the average variance extracted (AVE) has to be greater than the correlations which each dimension has with the rest of the dimensions. Table IV notes that this criterion is fulfilled in all the dimensions (diagonals in parentheses), except in Diversified financing which tends to be significantly related with strong networks, both belonging to the structural aspects of the EU.

Table $V$ offers the relative values of the HTMT criterion to establish the discriminant validity of the proposed variables. The data confirm this validity given that all the ratios are below the value of 0.9 .

In relation with the measurement model, we can state that, in accordance with the data presented in Tables II to $\mathrm{V}$, all the requirements for the validation of this model are met.

\section{Validation of the structural equation model and verification of hypotheses}

Respect to the structural model, the PLS methodology indicates that the regression
Table III. Average variance extracted (AVE).

\begin{tabular}{|c|c|}
\hline Dimensions & AVE \\
\hline Entrepreneurial culture & 0.758 \\
\hline Entrepreneurial curriculum & 0.650 \\
\hline Science and technology firms & 0.747 \\
\hline Applied research & 0.626 \\
\hline Entrepreneurial leadership & 0.726 \\
\hline
\end{tabular}

Source: 567 university students surveyed.

coefficient values $\left(R^{2}\right)$ of the final explained variable have to be taken into consideration; in our case, the results (creation of spin-offs and technology transfer) and the standardised regression weights between the model's pairs of variables. All the data referred to are shown in Figure 4 and indicate a high relation (Beta $=0.763$ ) between Entrepreneurial Culture and Entrepreneurial Curriculum. On the other hand, relationships between Entrepreneurial leadership and Entrepreneurial culture (Beta $=0.588$ ) and between Entrepreneurial leadership and Applied research (Beta=0.553) are also confirmed. Applied research also has a significant relation with Entrepreneurial curriculum (Beta=0.365). All the relations annotated underscore that the first 4 hypotheses are sustained by the data. As to the relations with $\mathrm{S}$ and $\mathrm{T}$ firm creation and technology transfer,

Table IV. Matrix of PLS discriminant validity under the Fornell-Larcker criterion of dimensions of the entrepreneurial university.

\begin{tabular}{|c|c|c|c|c|c|}
\hline & 1 & 2 & 3 & 4 & 5 \\
\hline Applied research (1) & $(0.791)$ & & & & \\
\hline Entrepreneurial culture (2) & 0.652 & $(0.871)$ & & & \\
\hline Entrepreneurial curriculum (3) & 0.700 & 0.763 & $(0.806)$ & & \\
\hline S and T firms (4) & 0.653 & 0.616 & 0.634 & $(0.864)$ & \\
\hline Leadership (5) & 0.774 & 0.588 & 0.605 & 0.555 & $(0.852)$ \\
\hline
\end{tabular}

Source: 567 university students surveyed. Elaboration: Own. 
it is noted that both variables (Entrepreneurial curriculum and Applied research) have positive and significant effects (Betas of 0.347 and 0.410 ), in contradiction with hypotheses 5 and 6 , which are not supported by the data.

To determine the level of significance of the values in Figure 4 a resampling test (bootstrapping) has been done with a total of 5,000 subsamples. The results obtained are shown in Table VI.

From the results presented, 4 of the 6 hypotheses are verified. Specifically, the two hypotheses related to the entrepreneurial leadership of universities and its effects on entrepreneurial culture (H1) and carrying out applied research $(\mathrm{H} 2)$. In this sense, the more inclined a university institution is to adopting an entrepreneurial approach, the more possible that it develops cultural changes oriented to fostering entrepreneurship as well as stimulating applied scientific research.

The idea that the introduction of cultural changes related with the stimulus of entrepreneurship involves the design of educational and professional curricula which place an emphasis on the promotion of entrepreneurship and derived attitudes and behaviours has also been supported.

On the other hand, the starting up of curricula centred on the fostering of the entrepreneurial behaviour of the distinct university groups has a clear positive effect on the design and implementation of applied research actions.

However, the two hypotheses related to the impacts on entrepreneurial results (spinoffs and technological transfer) have not been verified. To the contrary of what was proposed in the model analysed (null effects), the findings emphasise that the existence of an entrepreneurial curriculum and the fostering of applied research cause a growth in the number of firms created by universities.

\section{DISCUSSION AND CONCLUSIONS}

In this research a conceptual model has been proposed of the entrepreneurial university expressed from the literature review on the topic, in 9 dimensions or indicators: 1) decentralised leadership, 2) applied research, 3) structures of university-firm intermediation, 4) Science and Technology firms, 5) an entrepreneurial curriculum, 6) entrepreneurial support centres, 7) strong networks, 8) diversified financing and 9) entrepreneurial culture.

Via a quantitative approach, initial evidence has been contributed about the reliability and validity of the instruments designed to evaluate entrepreneurship in universities in Peru. Taking the case of one of the most important private universities in Peru, it has been found that the 9 dimensions proposed are reliable and valid and are related according to the conceptual model proposed. It has been identified in a sample of 567 students that 5 dimensions of the Entrepreneurial University are reliable, having interval consistency values by Cronbach's Alpha and Composite Reliability over 0.8 .

Four out of six hypotheses formulated have been verified, finding that there does exist an impact where it was predicted that they would be null.

In the ideal theoretical model, assuming a developed entrepreneurial university, all the relations established should have a significant impact and a large size effect. Yet, due to the idiosyncrasy of the Peruvian entrepreneurial university context, it was assumed that the USMP would have deficiencies in the impact of research on the entrepreneurial results. 
Table V. Discriminant validity (HTMT ratio) of dimensions of the entrepreneurial university.

\begin{tabular}{|c|c|c|c|c|}
\hline & $\begin{array}{c}\text { Applied } \\
\text { research }\end{array}$ & $\begin{array}{c}\text { Entrepreneurial } \\
\text { culture }\end{array}$ & $\begin{array}{c}\text { Entrepreneurial } \\
\text { curriculum }\end{array}$ & $\begin{array}{c}\text { S and T } \\
\text { firms }\end{array}$ \\
\hline Entrepreneurial culture & 0.696 & & & \\
\hline Entrepreneurial curriculum & 0.769 & 0.821 & 0.709 & \\
\hline S and T firms & 0.723 & 0.669 & 0.667 & 0.619 \\
\hline Leadership & 0.851 & 0.633 & 0 & 0 \\
\hline
\end{tabular}

Source: 567 university students surveyed. Elaboration: Own.

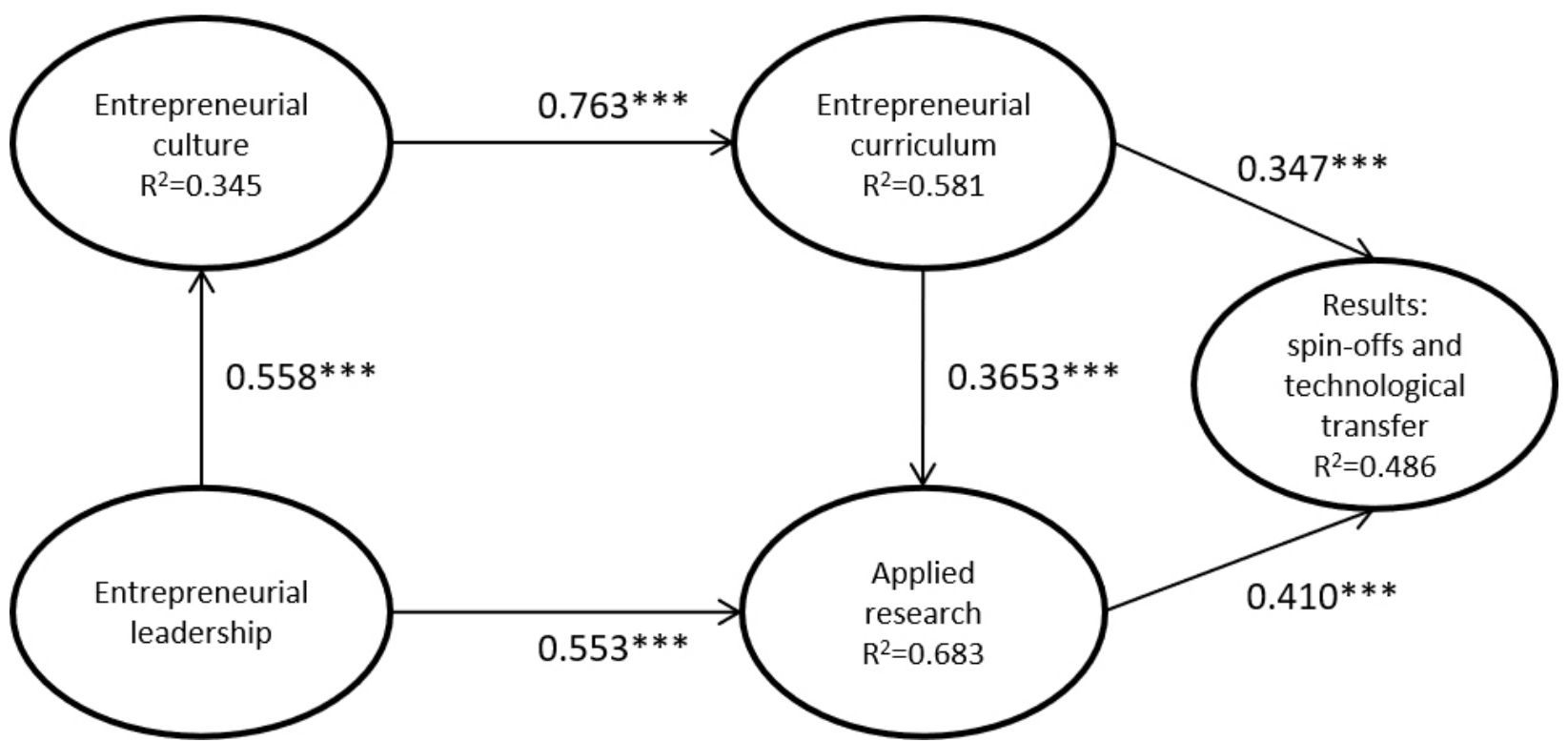

Figure 4. Results of causal relations of the proposed model.

Table VI. Significance of the path coefficients (beta) among constructs.

\begin{tabular}{|c|c|c|c|c|c|}
\hline $\begin{array}{c}\text { Relations between dimensions (Beta } \\
\text { values) }\end{array}$ & $\begin{array}{l}\text { Original } \\
\text { sample (0) }\end{array}$ & $\begin{array}{c}\text { Sample } \\
\text { average (M) }\end{array}$ & $\begin{array}{c}\text { Standard } \\
\text { error (STERR) }\end{array}$ & $\begin{array}{l}\text { T statistic } \\
\text { (|O/STERR|) }\end{array}$ & Supported \\
\hline $\begin{array}{l}\text { H1: Entrepreneurial leadership -> } \\
\text { Entrepreneurial culture }\end{array}$ & 0.588 & 0.588 & 0.033 & 18.086 & Yes \\
\hline $\begin{array}{l}\text { H2: Entrepreneurial leadership -> } \\
\text { Applied research }\end{array}$ & 0.553 & 0.552 & 0.037 & 14.807 & Yes \\
\hline $\begin{array}{l}\text { H3: Entrepreneurial culture -> } \\
\text { Entrepreneurial curriculum }\end{array}$ & 0.763 & 0.763 & 0.020 & 38.628 & Yes \\
\hline $\begin{array}{l}\text { H4: Entrepreneurial curriculum -> } \\
\text { Applied research }\end{array}$ & 0.365 & 0.367 & 0.036 & 10.232 & Yes \\
\hline $\begin{array}{l}\text { H5: Entrepreneurial curriculum -> } \\
\text { Spin-offs and Technological transfer }\end{array}$ & 0.347 & 0.345 & 0.057 & 6.074 & No \\
\hline $\begin{array}{c}\text { H6: Applied research -> Spin-offs and } \\
\text { Technological transfer }\end{array}$ & 0.410 & 0.412 & 0.054 & 7.538 & No \\
\hline
\end{tabular}

Source: Simulation via Bootstrapping. Resampling (5,000 times), $\mathrm{p}=0.01$ Note: Bootstrapping is a non-parametric procedure which is applied to test that the path coefficients (beta) are significant via the estimation of the standard errors for the estimations. 


\section{Limitations and future research}

This research has some limitations. Firstly, it has only been possible to achieve a sample of students. The entrepreneurial university is supported by three internal stakeholders: students, research teachers and administrative staff. A higher-quality analysis requires crossed information of the three groups. It remains for future researchers to use the instruments designed to obtain information of various interest groups.

Secondly, it has not been possible to obtain information from all the faculties. The faculties related with social sciences (Law, Communications, Psychology) have not taken part in the study.

Thirdly, given that this study only analyses the cultural aspects of the conceptual model offered in Figures 1 and 2, leaving aside the structural aspects, it is recommendable to replicate this research for the complete conceptual model.

Since this study represents the first empirical evidence of the conceptual model of the Entrepreneurial University, it is recommended to replicate the research in other Peruvian universities to test the validity of the proposed conceptual model. Thus, via comparative studies and from various centres, the discriminant power of the instruments could be tested, comparing universities with diverse levels of development in each dimension and the results obtained with the questionnaires.

\section{REFERENCES}

ALLEN T \& O’SHEA R. 2014. Building Technology Transfer within Research Universities: An Entrepreneurial Approach. Cambridge: University Press, 414 p.

AUDRETSCH DB. 2014. From the entrepreneurial university to the university for the entrepreneurial society. J Technol Transf 39(3): 313-321.
AUDRETSCH DB, KEILBACH MC \& LEHMANN EE. 2006. Entrepreneurship and economic growth. Oxford: University Press, 240 p.

BRAIDOT N. 2001. Educación para la Empresarialidad en el Contexto Universitario Argentino: ¿Opción O Necesidad? Universidad Argentina de la Empresa: Editorial Mimeo.

BREZTNITZ S \& ETZKOWITZ H. 2015. University Technology Transfer: The globalization of academic innovation. Routledge Studies in Global Competition, 502 p.

BRUNNER J. 2006. Mercados universitarios: Ideas, instrumentos y seis tesis en conclusión. Santiago: Universidad Adolfo Ibáñez.

CARGILL BJ. 2007. Learning about the entrepreneurial university: do we know what it means? Do we know what it takes to succeed? S African J Sci 21(3): 373-384.

CLARK B. 1998. Creating Entrepreneurial Universities: Organizational Pathways of Transformation. Oxford: IAU Press, Pergamon-Elsevier, 163 p.

ETZKOWITZ H. 2002. MIT and the rise of entrepreneurial science. New York: Routledge, 192 p.

ETZKOWITZ H. 2004. The evolution of the entrepreneurial university. Int J Technol Glob 1(1): 64-77.

ETZKOWITZ H. 2013. Anatomy of the entrepreneurial university. Soc Sci Inf 52(3): 486-511.

ETZKOWITZ H \& LEYDESDORFF L. 1996. Emergence of a triple helix of university-industry-government relations. Sci Public Policy 23: 279-286.

FARNHAM D. 1999. Managing Academic Staff in Changing University Systems: International Trends and Comparisons. Open University Press, 325 Chestnut Street, Philadelphia, 376 p.

FOSS L \& GIBSON D. 2015. The Entrepreneurial University: Context and Institutional Change. Routledge Studies in Innovation, Organization and Technology, New York: Routledge, 312 p.

HAHN D, MINOLA T, BOSIO G \& CASSIA L. 2019. The impact of entrepreneurship education on university students' entrepreneurial skills: A 2family embeddedness perspective. Small Bus Econ 1-26.

HARRISON C, BURNARD K \& STUART P. 2018. Entrepreneurial leadership in a developing economy: A skill-based analysis. J Small Bus Enterp Dev 25(3): 521-548.

HIDALGO A \& MOLERO J.2008. Tecnología en industrialización en el despegue de la economía española: nuevas perspectivas a partir de las patentes. In: Corona $L$ and 
Molero J (Coord) Los retos de la innovación en México y España. Madrid: Akal.

KHAN CBA \& AHMED R. 2019. Organizational culture and entrepreneurial orientation: Mediating role of entrepreneurial leadership. Bus Econ Rev 11(4): 149-178.

MARQUES HR, OLIVEIRA TA, ANDRADE DM \& ZAMBALDE AL. 2019. University entrepreneurship in brazil. World Rev Entrepreneurship, Manag Sustain Dev 15(2): 149-158.

MAUTNER G. 2005. The entrepreneurial university: A discursive profile of a higher education buzzword. Crit Discourse Stud 2(2): 95-120.

MEYERS A \& PRUTHI S. 2011. Academic entrepreneurship, entrepreneurial universities and biotechnology. J Commer Biotechnol 17(4): 349-357.

MORALES-GUALDRÓN S. 2008. El emprendedor académico y la decisión de crear spinoff: Un análisis del caso español. thesis. Valencia: Universidad de Valencia.

MUNGER M. 2015. The Third Entrepreneurial Revolution: A Middleman Economy. Unpublished manuscript, Department of Political Science, Department of Economics of Duke University, Sanford School of Public Policy, United States.

PAUNOVIC S. 2007. Entrepreneurial university - Innovative approach to learning and/or significant changes in the way universities operate. European Entrepreneurship Education. https://www.umfst.ro/proiecte/EEE/ results_5.html.

PÉREZ P \& MÁRQUEZ A. 2006. Análisis del sistema de incubación de empresas de base tecnológica en México. I Congreso Iberoamericano de Ciencia, Tecnología, Sociedad e Innovación CTS+I. Palacio de Mineria, from 19 to 23 June.

PINEDA P. 2015. The Entrepreneurial Research University in Latin America: Global and Local Models in Chile and Colombia, 1950-2015. Palgrave Macmillan, 265 p.

RINGLE CM, WENDE S \& BECKER JM. 2015. "SmartPLS 3." Boenningstedt: SmartPLS GmbH.

RODEIRO D, FERNÁNDEZ S, OTERO L \& RODRÍGUEZ A. 2008. La creación de empresas en el ámbito universitario: una aplicación de la teoría de los recursos. Cuad Gestión 8(2): 11-28.

RÖPKE J. 1998. The entrepreneurial university. Innovation, academic knowledge creation and regional development in a globalized economy. Working Paper Departmanet of Economics, Philipps-Universität Marburg, Germany:15.

SALAMZADEH A, SALAMZADEH Y \& REZA M. 2011. Toward a Systematic Framework for an Entrepreneurial University: A Study in Iranian Context with an IPOO Model. Int J Bus Manag Res 3(1): 31-37.

SHANE E. 2004. Academic entrepreneurship: university spinoffs and wealth creation. Edward Elgar Publishing, $335 \mathrm{p}$.

SHARMA P \& CHRISMAN JJ. 1999. Toward a reconciliation of the definitional issues in the field of corporate entrepreneurship. Entrep Theory Pract 23(3): 11-27.

VALERA-LOZA D. 2006. La enseñanza y promoción del comportamiento emprendedor en la Universidad: Estado de las investigaciones empíricas 1975-2005. Thesis presented in the Universidad de Sevilla. Programa de Doctorado en Administración de Empresas. June 2006. Seville.

VALLS J \& CONDOM P. 2003. El auge de la universidad: La universidad emprendedora. Iniciativa emprendedora y empresa familiar (41): 5-12.

VALLS J, CONDOM P \& BIKFALVI A. 2008. Universidad y empresas innovadoras: Estrategias universitarias de apoyo a la creación de empresas spin-off. In: Corona $L$ and Molero J (Coord) Los retos de la innovación en México y España. Madrid: Akal.

\section{How to cite}

VALERA-LOZA DH, DEL JUNCO JC \& PALACIOS-FLORENCIO B. 2021. Conceptual model about the entrepreneurial university: design and validation with the PLS methodology. An Acad Bras Cienc 93: e20200494. DOI 10.1590/0001-3765202120200494.

Manuscript received on April 10, 2020;

accepted for publication on June 24, 2020

\section{DANIEL HERNÁN VALERA-LOZA ${ }^{1}$}

https://orcid.org/0000-0001-8683-9816

JULIO GARCÍA DEL JUNCO ${ }^{2}$

https://orcid.org/0000-0003-0338-150X

BEATRIZ PALACIOS-FLORENCIO ${ }^{3}$

https://orcid.org/0000-0003-2789-7914 
${ }^{1}$ Facultad de Ciencias Administrativas y Recursos

Humanos, Universidad San Martín de Porres, Jr. Las

Calandrias № 151-291, Santa Anita, Lima, 43 -15009 Perú

${ }^{2}$ Departamento de Administración de Empresas y

Comercialización e Investigación de Mercados (Marketing),

Facultad de Ciencias Económicas y Empresariales, Universidad

de Sevilla, Avda. Ramón y Cajal №1 41018, Seville, Spain

${ }^{3}$ Departamento de Organización de Empresas y Marketing,

Facultad de Ciencias Empresariales, Universidad Pablo

de Olavide, Carretera Utrera, Km.1, 41013, Seville, Spain

Correspondence to: Beatriz Palacios-Florencio

E-mail:bpalacios@upo.es

\section{Author contributions}

Daniel Hernán Valera Loza has carried out the data collection, drafting of conclusions and review of the article. Julio García del Junco has written the review of the literature and Beatriz Palacios Florencio has made the treatment of the methodological part and writing of the results.

\section{(cc) BY}

